sound. (3) Conseil Central des Observatoires. I5,000 francs to the Observatory of Paris for the improvement of astronomical instruments applied to the determination of time. I 500 francs to the Observatory of Marseilles for ensuring the publication of the Journal des Observateurs.. (4) Ecole Nationale Vétérinaire d'Alfort. 7000 francs to this school for the purchase of an apparatus for kinematographic registration and projection; this will be of great service in the study and demonstration of various movements in the normal or pathological state. (5) Ecole Nationale Vétérinaire de Lyon. 850 francs to Charles Porcher for the purchase of instruments to be used in his researches on milk. Soo francs to François Maignon for the purchase of a balance and a small hydraulic press, to be used in his researches on nutrition. (6) Ecole Nationale Vétérinaire de Toulouse. 5000 francs to this school for a radiological installation to be used in the diagnosis of diseases of animals.

II. Establishments Nominated to the Committee by the President of the Academy.-(I) Conservatoire des Arts et Métiers. 4000 francs to Louis Blaringhem for the creation of a typical collection for the determination and classification of the woods used in the aeronautic industry. 5000 francs conditionally to James Dantzer for the creation of a laboratory for the testing of textiles, fibres, and tissues under the express condition that the Union des Syndicats Patronaux de 1'Industrie Textile contributes the same amount. Ecole Nationale Supérieure des Mines. Io,00o francs to this school for completing the laboratory installation, especially as regards motive power. (3) Institut Catholique de Paris. 2000 francs to Henri Colin for the purchase of apparatus not usually found in botanical laboratories, to be used in his researches on the conditions of destruction of various bacilli. 2000 francs to Jules Hamonet for purchasing apparatus for determining the physical constants, particularly refractive indices, of the new substances he has discovered in the glycol group.

III. Various Direct Requests for Grants.To, oo francs to Jules Garçon for the preparation of a bibliography of bibliographers, a part to be used in making an inventory of the scientific periodicals contained in the libraries of Paris. 3000 francs to Guil. laume Bigourdan for the construction of an angle comparator for measuring the variation which the angular distance of two stars may show in a short interval of time. 3000 francs to Henri Bourget for his researches on astronomical photometry. 2000 francs to A. Col. son for continuing his researches on solutions. 7000 francs to Augustin Mesnager for improving the equipment of the laboratory for testing materials under his direction at the Ecole des Ponts et Chaussées. 2000 francs to Jules Glover for continuing his researches on telephony. 7000 francs to Louis Jobin to complete the publication of his studies relating to the material collected in the second Antarctic voyage of Jean Charcot. 5000 francs to the Société de Documentation Paléontologique. 2000 francs to J. M. R. Surcouf for assisting the publication of his work on horse-flies.

The total amount in grants is II 5,200 francs.

\section{THE U.S. NATIONAL RESEARCH COUNCIL.}

THE December, 1916, issue of the Proceedings of the U.S. National Academy of Sciences contains reports of meetings of the council on November I 3 and I4 last, and of the meetings of the Executive Committee of the council held during October and November. At these meetings several committees were ap. pointed to deal with specific questions. Among these may be mentioned that to confer with representatives of the National Canners' Association in the conduct

No. 2466 , VOL. 98$]$ of investigations on toxic elements in canned foods; that to co-operate with the Government Committee on Ocean Surveys and Ice Patrol; that on the utilisation of industrial research facilities for the national defence; that to consider the organisation of research in anthropological and sociological. sciences; and general committees (in addition to that on chemistry previously established) on mathematics, astronomy, physics, geology and palæontology, geography, botany, zoology and animal morphology, physiology, medicine, hygiene, agriculture, psychology, and anthropology.

At the meetings of the council in November several members gave addresses, one of which, on scientific research for national defence as illustrated by the problems of aeronautics, was by Lieut.-Col. G. O. Squier, and of this we print an abstract from the Proceedings of the National Academy.

Scientific Research for National Defence as Illustrated by the Problems of Aeronautics.

The following are some present problems connected with the development of military aviation and aerostation.

r. Aerodynamics.--(a) Continue the development of the mathematical theory to explain the aerodynamic phenomena recorded in the aerodynamical laboratories, and to forecast further results.

(b) Obtain solutions for the speed and direotion of flow of air about geometric and aenotechnic forms and develop experimental means to visualise or map the speed and direction of flow.

(c) Map the currents of the upper atmosphere which may be of most use in aerial navigation, and evolve simple practical rules for the guidance of pilots.

(d) Give fuller explanation of the phenomena of soaring, i.e. airplaning indefinitely without motive power.

(e) Develop equations and laws of comparison by which the behaviour of large aircraft may be more accurately foretold from tests of models. Apply further the principle of dynamical similarity.

$(f)$ Investigate more direct and effective methods of securing a lift or thrust in the air from the consump. tion of fuel.

(g) Complete theory of the air-screw.

2. Engine Problems Requiring Research.-(a) Fuel. Possibly the most far-reaching problem is fuel. A fuel that will carry more power into an engine per unit volume will be a direct gain.

Attempts have been made to combine alcohol, gaso. lene, acetylene, picric acid, ether, and other hydrocarbons with the above object in view. Questionable results have followed. There has been an increase of power, but nothing so far commercially or practically useful.

This question must be studied with the greatest of care and from a truly research point of view.

(b) Solid fuel. Solid fuels that can be converted into liquid in small quantities just prior to use are desirable for military aviation. In case of accident from shot or shock, leakage of liquid fuel is a danger. Solid fuel could be carried in quantity with less danger.

(c) Engine cooling. The problem of radiation is important. If some substance could be found that would circulate through the cooling system, at higher temperatures than water, it is probable that greater engine efficiencies would result. Oils, salt waters, and other materials have been tried with indifferent success.

(d) Liquid-fuel pipes. Tubing that will resist vibration (causing rupture) is desired. An dil and gasolene proof rubber tubing is reported as used in Europe. This development is highly important, not only for tubing, but for containers in which to carry liquid fuel. Some sort of fabric and rubber tank that would 
really resist the action of gasolene would be of the highest benefit.

A difficulty lies in the fact that the tanks are large (say zo to roo gallon capacity). The structural problems would be serious. The tanks now used are large and of metal. Vibration causes much difficulty and leakage.

(e) Metal coating. The protecting of the metal parts of an airplane, especially the fittings and cables, is a serious problem. A material is desired that would really prevent dangerous corrosion. Nickel-plating over copper is very good, but will not suffice. Rust strikes through very rapidly. Baked enamel is the best coating. It is impossible to apply in many cases.

(f) Sound. The auestion of eliminating the noises involved in the operation of aircraft is one of importance. The peculiar note of the propeller of a Zeppelin can be heard for several miles, and is usually the first warning of its approach at night.

3. Miscellaneous.-(a) Physiological. Study the physiological and psychological effects of low-density air at high altitudes on the performanice of pilots.

(b) Transparent wing covering for airplanes. wing covering. which would answer the following general requirements would be of great value to military aviation :-

Weight not more than $5 \mathrm{oz}$. per square yard.

It should present reasonably great resistance to flame.

It should be reasonably proof against action of salt water, moist air, extreme dryness, and quick temperature changes.

It should not stretch in any direction. Its ability to retain its original form as placed on the airplane is very important.

It should have tensile strength of at least $75 \mathrm{lb}$. per inch width in any direction.

Its tendency to tear and split because of tack holes through it, or because of bullet holes, should be as small as possible.

(c) Development of light alloys for airplane construction. Pure aluminium or aluminium alloys. It is believed that a great deal can be done in this direction. So far no alloy has been developed, except pos. sibly in Germany, which can compare with average Alaskan spruce in its "specific tenacity."

$(d)$ The structure of gusts. It is believed that this is of sufficient importance to aviation to warrant considerable expense in its study.

Painstaking investigation of the character of eddy formations caused when wind strikes trees, hollows, cliffs, etc., and the character of disturbances created by canyons, swamps, deserts, etc., would be of great value to aviators.

This can be done not only by smoke and toy balloon work in the vicinity of obstructions such as the above, but also by photographic work in wind channels.

A set of simple rules laying down just what the aviator may expect on one side or another of canyons, cities, trees, lakes, and swamps would be very helpful in aviation.

(e) Radio-apparatus for aircraft. The subject of radio-intercommunication between aircraft in flight, and between airoraft and the earth, requires for its solution the highest possible efficiency and trustworthiness combined with minimum weight.

A present tendency is to separate entirely. the power plant from the main engine of an aircraft. The generator body in this case has a stream-line figure, and a separate small air-screw is provided. Among other methods the oscillion is being tried as the actual source of continuous electromagnetic waves.

(f) Bullet-proof gasolene tanks. Development of a material with which to line or construct tanks to contain the gasolene in an airplane in which a bullet hole NO. 2466, VOL. 98] will quickly close, entirely or at least partly. This would enable many a flyer to get back to his own lines after having been fired upon.

(g) Development of a fabric as good as, or better than, Irish linen for the covering of airplanes. There has not been manufactured in the United States a fabric suitable for use in covering airplanes.

The fabric should answer all requirements laid down under transparent wing covering, and be, in addition, such as to shrink the proper amount without harm when cellulose solution is applied.

It is possible that long-fibre cotton might be developed that would answer the purpose.

We must become independent in all lines affecting our military aviation. To-day we depend entirely upon Ireland and England for our linen, and the supply is becoming very low in the United States.

(h) Aviator's clothing. Much has still to be done in devising non-inflammable and protective clothing for aviators. This question is intimately connected with personal armour and safety in case of fall.

(i) Ground-speed indicator. An instrument which would measure the actual speed of an aircraft over the ground would be useful in the operation of military machines.

4. Physics of the Air.-A number of physical properties of air, important in the problems of aviation, were also discussed.

\section{UNIVERSITY AND EDUCATIONAL INTELLIGENCE.}

Birmingham.--Miss Helen Caddick has presented to the University a valuable collection of examples of the art of primitive peoples. The collection, which has been made by Miss Caddick in numerous travels, includes specimens from Central Africa, Tonga and Fiji Islands, New Zeraland, and Peru. It is hoped that the gift may form the nucleus of an ethnological museum for the University.

LoNDON.-At a meeting of the Senate held on January 24, the Vice-Chancellor (Sir Alfred Pearce Gould) being in the chair, Mr. J. J. Guest, of Trinity College, Cambridge, was appointed as fnom February I2 next to the University readership in graphics and structural engineering tenable at University College, in succession to Dr. W. H. Eccles, reader in graphics, who has been appointed professor of applied physics and electrical engineering at Finsbury Technical College.

The following doctorates have been conferred by the Senate:-In Chemistry: Mr. Guy Barr, an external student, for a thesis entitled "Researches in Relation to the Tensile Strength of Fabric, and the Effects of Experimental Vartiations on the Result of Tensile Tests," and other papers. In Botany: Mr. R. C. Mclean, an external student, for a thesis entitled "Studies in the Ecology of Tropical Rain Forests," and other papers.

OXFORD.-On January 30 the preamble of the Statute creating the status of "advanced student" and prescribing the conditions on which advanced students may obtain certain degrees came before Congregation. An able speech in favour of the Statute was delivered by the Rev. E. M. Walker (Queen's), who was supported by Prof. Perkin, Waynflete professor of chemistry, and as to the principle of the Statute by Mr. S. Ball (St. John's), Dr. Macan, Master of University College, and Dr. F. C. Schiller (Corpus). The last three speakers argued in favour of the degree of doctor of philosophy being offered under the Statute, instead of that of D.Sc. or-D.Litt. as was at present contemplated. Notice was given of an amendment to be proposed in this sense. The only 